\title{
Josephus on How to Survive Martyrdom
}

\author{
Steve Weitzman \\ University of Indiana
}

W ho invented martyrdom? As Daniel Boyarin has noted, scholarship offers two basic answers to this question. ${ }^{1}$ In a highly influential study, William Frend found the origins of the idea of martyrdom in Judaism of the Second Temple period. ${ }^{2}$ There were Greeks and Romans willing to sacrifice their lives for various reasons, he admits, but they did so for political causes; dying for one's religion was a Jewish idea. More recent scholarship seems inclined to give credit to non-Jews and most especially the Romans and their traditions of voluntary death. G. Bowersock, doing what he can to minimise the Jewish contribution to this concept by dating key sources like $2 \mathrm{Mac}$ cabees 7 as late as he can, is one such scholar, arguing that martyrdom proper only developed under the influence of Roman fatal charades, the theatre of its executions. ${ }^{3}$ For Frend, martyrdom was an innately Jewish concept, rooted in biblical spirituality and coming into its own in confrontation with pagan culture during the Maccabean crisis. For Bowersock, martyrdom was an essentially Roman inheritence, Jewish and Christian conceptions of martyrdom arising not just in response to imperial rule but under the influence of its urban institutions and cultural orientation.

Enter the Jewish historian Flavian Josephus, a source virtually ignored by Bowersock but with a lot to say on the subject. Although he clearly had his failings as an anthropologist, Josephus remains our most important informant for Jewish religious practice in the late Second Temple period. As a denizen of Rome and an intimate of the Flavian emperors, he also knew something about Roman culture. ${ }^{4}$ Josephus thus seems perfectly positioned to speak to the question at hand: what were the relative contributions of Judaism and Roman culture to the development of the practice now known as martyrdom?

The closer one reads Josephus' historical narratives, however, the harder it is to understand what it is exactly he is saying about dying for one's religion, depicting the practices of suicide and martyrdom in equivocal, even self-contradictory terms. ${ }^{5}$ On the one hand, Jewish culture as he describes it

1 See D. Boyarin, Dying for God: Martyrdom and the Making of Christianity and Judaism (Stanford University Press, Stanford, 1999), pp. 93-94.

2 W. Frend, Martyrdom and Persecution in the Early Church: A Study of a Conflict from the Maccabees to Donatus (Anchor Books, Garden City, NY, 1965), pp. 31-78.

3 G. Bowersock, Martyrdom and Rome (Cambridge University Press, Cambridge, 1995).

4 See T. Rajak, Josephus: the Historian and His Society (Fortress Press, Philadelphia, 1984), pp. 185-222; M. Goodman, 'Josephus as Roman Citizen', Josephus and the History of the GrecoRoman Period: Essays in Memory of Morton Smith, ed. F. Parente and J. Sievers (Brill, Leiden, 1994), pp. 329-38.

5 Although the terms 'suicide' (intentionally taking one's own life) and 'martyrdom' (the willing acceptance of death) denote very different kinds of practice, there is overlap between them in Jewish sources like 4 Maccabees and Josephus as variant forms of 'voluntary death', and 
does indeed seem to fit Frend's characterisation of it. A recent survey of his literary corpus finds 62 accounts of voluntary death there, and in many of these scenes, the act of voluntary death is motivated by the pious wish to defend Jewish tradition or an uncompromising commitment to God. ${ }^{6}$ Josephus reports in the Jewish War that he himself had been 'prepared to die' to save Jerusalem from destruction (J.W. 5.419). In Against Apion, written twenty or so years after the Jewish War, the willingness to die has become a national trait of the Jews:

It is an instinct with every Jew, from the day of his birth, to regard (the Scripture) as the decrees of God, to abide by them, and, if need be, cheerfully to die for them. Time and again, ere now the sight has been witnessed of prisoners enduring tortures and death in every form in the theatres, rather than utter a single world against the laws and the allied documents. (Against Apion 1.43)

It is true that Josephus does not say outright that Judaism was a religion of marytrdom, a word not used in this way for a few more centuries, but he comes close in this passage, describing it as a culture poised to die for its traditions.

In other passages, on the other hand, Josephus expresses deep reservations about taking one's own life, discrediting it as a rash and even impious act. $\mathrm{He}$ is most explicit in his description when explaining his own refusal to commit suicide during the Jewish Revolt. In 67 C.E, Josephus and his men found themselves pinned down by the Romans in a cave at Yodefat (also known as Jotapata) with no avenue of escape. Many of their comrades had already taken their lives by that point (J.W. 3.331) and the remainder now resolved to do so too. Given what he says elsewhere about Jews cheerfully dying for the law, one might think that Josephus would have gladly joined them, but in fact he reports that he did everything he could to talk them out of it, appealing to philosophical and theological arguments against suicide in a lengthy speech. He points out that nature itself opposed suicide; among animals, after all, there is not one that deliberately seeks to kill itself (369-70). God rejects it too, condemning suicides to hell and punishing their posterity (375-77). Josephus' men were unmoved by his appeal, threatening to kill him if he did not do so himself, but Josephus confides to the reader that he had another reason to oppose it: chosen by God as a prophetic messenger, he had to live long enough to inform Vespasian he was destined to become emperor. To fulfill that duty, he declared himself ready to die and proposed a lottery for determining who was to kill whom. Happily, however - with the help of providence or some ruse- Josephus managed to be among the last two soldiers standing, and persuading the other that it was best to remain alive, they surrendered to

they were only clearly distinguished later. See Bowersock, Martyrdom and Rome (as in n. 3), pp. 59-74.

6 J. Willem Van Henten, 'Noble Death in Josephus: A Survey' (paper presented at the annual meeting of the Society of Biblical Literature in Denver, Colorado, 2001). Much of the data can also be found in R. Newel, 'The Suicide Accounts in Josephus: A Form-Critical Study', SBL 1982 Seminar Papers, ed. K. Richards (Scholars Press, Chico, CA, 1982), pp. 351-69; idem, 'The Forms and Historical Value of Josephus' Suicide Accounts', Josephus, the Bible and History, ed. L. Feldman and G. Hata (Wayne State University Press, Detroit, 1989), pp. 278-94. 
the Romans (387-91). While elsewhere, the historian seems to corroborate the impression of Judaism as a religion of martyrdom, the Josephus of this scene ardently dissents from this ethic, completely disavowing voluntary death as irrational and impious.

What are we to make of this apparent inconsistency? If Josephus admired the act of voluntary death, why impute to himself a lengthy speech that discredits it as a violation of natural and divine law? If he disapproved of it, why accentuate its heroic dimension in so many scenes, and why make it so essential to Jewish identity in Against Apion, a work meant to defend the Jews against their critics? Was he too careless or incompetent to smooth out the inconsistencies in his narrative? In the past, scholars have characterised him in this way-some even believe that assistants wrote parts of his work-and in the light of such a view, there is little point in trying to decode or resolve Josephus' inconsistent treatment of voluntary death. ${ }^{7}$ The Josephus of contemporary scholarship is usually given more credit than this, however, actively shaping his narratives to serve his own agenda ${ }^{8}$ Under the influence of this conception, recent scholars have found it hard to believe that the historian's treatment of voluntary death is really as flatly self-contradictory as it appears.

David Ladouceur has sought to resolve the inconsistency by pointing to ways in which Josephus discredits the arguments in favour of suicide made by the rebel Eleazar before the mass suicide at Masada. ${ }^{9}$ Eleazar's speech may seem to make a compelling case for suicide, echoing contemporary Stoic and Cynic arguments, but Josephus undercuts its claims by putting it into the mouth of a brutal rebel, and then, in the ensuing narrative, accentuating the brutality and irrationality of the act itself. In this reading, Josephus only seems inconsistent because the modern reader misses ironic touches that have been obscured in translation.

For Arthur Droge and James Tabor, the key to understanding Josephus is to recognise his indebtedness to Plato and his account of Socrates willing death. ${ }^{10}$ Socrates as portrayed in Plato's Phaedo also seems to contradict himself on the subject of suicide, at first glance, forbidding his disciples to commit suicide, yet preparing to take his own life. When his students wonder at this, Socrates explains: 'a person must not kill himself until god sends some necessity upon him, such as now come upon me' $(62 \mathrm{c}) .{ }^{11}$ This principle - the presence of a divine sign signalling death's necessity — governs Josephus' own assessment of suicide, Droge and Tabor argue. At Masada, for instance, God had sent a sign to the rebels that it was time for them to die by turning a fire that had been driving against the enemy back toward the rebels (J.W. 7.332.

\footnotetext{
${ }^{7}$ For a survey of scholars with this view, see P. Bilde, Flavius Josephus Between Jerusalem and Rome: His Life, His Works and their Importance (Sheffield Academic Press, Sheffield, 1988), pp. $123-41$.

8 Bilde, Flavius Josephus (as in n. 7), pp. 141-50.

9 D. Ladouceur, 'Masada: A Consideration of the Literary Evidence', Greek, Roman and Byzantine Studies 21 (1980), pp. 245-60.

10 A. Droge and J. Tabor, A Noble Death: Suicide and Martyrdom among Jews and Christians in Antiquity (HarperSanFrancisco, San Francisco, 1992), pp. 93-95.

11 For analysis of how the Platonic Socrates views suicide, see now J. Warren, 'Socratic Suicide', Journal of Hellenic Studies 121 (2001), pp. 91-106.
} 
cf. 358). This suicide thus met Socrates' criteria for a morally sanctioned act. In Josephus' own case, by contrast, there was no necessity to die, and no divine sign; to the contrary, God had signaled that he wanted Josephus to live by sending him dreams about the future on preceding nights (3.351-55), and, perhaps, by arranging to have him chosen last in the lottery. It would have been immoral for a person in this circumstance to have taken his life (3.365). In this reading, what seem like two seemingly antithetical positions, one endorsing suicide, one opposing it, become complementary elaborations of a single, thoroughly consistent Platonic stance.

Although certainly plausible, both of these explanations make one presumption in their approach to Josephus that I wish to contest; both assume that the impression of ambivalence in Josephus' suicide accounts is a misreading - or rather an underreading - imposed on the text by readers without the cultural background to detect its irony or to recognise the philosophical tradition behind it. Against this view, I believe it possible that Josephus intended to send a mixed message in his suicide reports, to seem equivocal. In what follows, I shall argue for this hypothesis by reading Josephus in comparison with the suicide accounts of contemporary Roman writers from the Flavian age - Statius, Valerius Flaccus and Silius Italicus - all active in the exact same period, 80-100 C.E., in which Josephus wrote his major works. Reading Josephus in relation to contemporary literary practice reveals what an author in his circumstances had to gain from seeming ambivalent about suicide.

\section{Self-Killing in a Flavian Context}

Roman imaginations in the first century C.E. were deeply enamoured of 'noble death,' the willing acceptance of death or taking one's own life to avoid defeat, captivity or dishonor. Suicides done for the right reason and in the right way, calmly and deliberately, were celebrated as heroic acts: the deaths of Cato and Seneca became exempla of philosophic heroism, and the selfsacrifice of a general or soldier on the battlefield, a practice known as devotio, was considered the height of military valour - and a highly effective strategem as well, able to reverse the course of a losing battle. ${ }^{12}$ Roman sources give the impression that suicide was extremely common. ${ }^{13}$ Whether that is so or not, it was certainly a prevalent theme in Roman prose and poetry from this period, taking centre stage in the writing of Seneca, Lucan, and other well-known writers.

Of particular interest here is the role of suicide in the epic narratives of three

\footnotetext{
12 For philosophically motivated suicide in first-century Rome, see M. Griffin, 'Philosophy, Cato, and Roman Suicide', Greece and Rome 33 (1986), pp. 64-77, 192-202. For the practice of devotio, see H. Versnel, 'Self-Sacrifice, Compensation and the Anonymous Gods', Le sacrifice dans l'antiquité: huit exposés suivis de discussions, ed. O. Reverdin and J. Rudhardt (Fondation Hardt, Vandœuvres and Geneva, 1981), pp. 135-94.

13 For review of the evidence, see Y. Gríse, Le suicide dan la Rome antique (Bellarmin, Montreal, 1983); A. van Hooff, From Autothanasia to Suicide: Self-Killing in Classical Antiquity (Routledge, London, 1990).
} 
Flavian poets, Statius, Valerius Flaccus and Silius Italicus. In a recent analysis of these narratives, Donald Mcguire makes several observations about these authors that remind one of Josephus' suicide accounts composed in the same period: All three made suicide a central theme in their writing. ${ }^{14}$ All three emphasised its political significance as a form of freedom no tyrant could compromise; and most significantly for us, all were equivocal in their depictions of the act, insinuating reservations about it even as they seem to extol it.

Reflecting all three of these trends, for instance, is Silius' epic the Punica, a poem of 12,000 verses that tells the story of the second Punic War between the Romans and Hannibal. Early in the poem, Silius recounts Hannibal's conquest of the city of Saguntine in southern Spain, a key battle leading up to Hannibal's conflict with the Romans themselves, and one that-like the Jewish Revolt - culminated in a mass suicide. What is relevant for our purposes about Silius' description of the Saguntines' suicides, acts that he refers to paradoxically as 'crimes that deserve praise', laudandaque monstra (Punica 2.650 ), is the contradictory signals it sends. The narrator does indeed praise the suicides as an heroic deed which 'glory in defeat keeps famous forever throughout the world' (2.612-13), but he also saps their moral lustre by associating the deaths with the crimes of fratricide, parricide and uxoricide:

Against their will men stain their hands with kindred blood; they marvel at the crime they have committed with loathing, and weep over the wickedness they have wrought. One man, distraught with rage and the madness of disaster and extreme suffering, turns a sidelong glance at the breast of his mother. Another, snatching an ax and aiming it at the neck of his loved wife; reproaches himself and curses his unfinished crime. $(2.617-24)^{15}$

Silius not only emphasises the horror of the act; he projects that response onto the actors within the narrative, picturing the Saguntines, cast in the double role of perpetrator and spectator, as aghast at their own actions. Valerius Flaccus and Silius are similarly equivocal, focusing on suicide as a form of courageous resistance to tyranny, but also registering its savagery and selfcensoring effect.

Greco-Roman philosophers, we have noted, had long been of two minds about suicide, often registering objections to it as Socrates did. But like Plato, they noted these objections in order to address them, often doing so by distinguishing between legitimate and illegitimate forms of self-killing. The suicides of Flavian Epic cannot be judged in such a clear-cut way: they are heroic and criminal at the same time, resisting tyranny but doing its work for it by silenc-

14 See D. McGuire, 'Textual Strategies and Political Suicide in Flavian Epic', The Imperial Muse: Ramus Essays on Roman Literature of the Empire, vol. 2, ed. A. Boyle (Aureal, Victoria, 1990), pp. 21-45; idem, Acts of Silence: Civil War, Tyranny and Suicide in the Flavian Epics (Olms and Weidman, Hildsheim, 1997), pp. 185-229. For another reading of the suicide theme in these epics, one that stresses only their valorisation of suicide, see F. Ripoll, La Morale Hérö̈que dans les Épopées Latins d'Époque Flavienne: Tradition et Innovation (Peeters, Louvain and Paris, 1998), pp. 373-424.

15 The translation is that of J. Duff, Silius Italicus: Punica (Loeb edition; Harvard University Press, Cambridge, MA, 1934). 
ing the opposition, and mimicking the tyrant's madness and pitiless brutality. McGuire believes the mixed signalling is deliberate, a rhetorical strategy that allowed poets to explore a subversive theme without being pinned down by imperial censors. Writing about suicide in the Flavian period could be dangerous precisely because of the act's role as a way to protest against tyranny. ${ }^{16}$ That philosophers like Seneca had concluded that suicide was the only expression of freedom left to them suggested that the world they lived in, the Roman empire, was no longer free. At the same time, the assertion of this freedom exposed a crack in the emperor's power, an autonomous realm of action over which he could assert no control. There may have been nothing a ruler could do to punish those who chose to defy him by killing themselves, but there was a way to keep people from celebrating that act or the defiant posture it seemed to endorse: punish those who extolled suicide. In the Flavian period, authors were indeed punished for praising certain acts of defiant suicide by an eagle-eyed Flavian dynasty on the lookout for literary treachery. ${ }^{17}$ To cite a case from the reign of Domitian, the author Junius Arulenus was executed for treason because he used the word 'holy' to describe Thrasea Paetus, a Stoic who killed himself after being sentenced to death by Nero (Dio 67.13).$^{18}$ McGuire argues that the equivocation of Flavian epic, the way it undermines its own heroic portrait of suicide, is an attempt to evade the peril of writing about this subject. The ambiguity of these suicide reports, this argument suggests, reflects a survival strategy to which Greek and Roman writers often resorted in the Flavian age, the 'art of safe criticism'-the use of doublespeak, ambiguity and other shifty rhetorical manoeuvres to make risky statements without getting into trouble. ${ }^{19}$

Might the ambivalence of Josephus' suicide accounts also reflect this trend? Let us consider Josephus' famous account of the mass suicide at Masada as a case study. His account certainly contains a number of elements that would have resonated as heroic for a Roman reader: the rebel commander Eleazar gives two lengthy speeches that make suicide appear like a reasoned and pious act undertaken to preserve freedom and nobility (J.W. 7.323-88), and his language evokes the Phaedo and other classical precedents perhaps recognisable by sophisticated Roman readers. ${ }^{20}$ Reinforcing the impression of the act as heroic is the response of Roman spectators within the narrative, the soldiers who discover the bodies of the slain: 'instead of exulting as over enemies, they admired the nobility of their resolve and their contempt of death' (7.406).

Even as it sends out these positive signals, however, the narrative calls the rationality of the act into question, and in much the same way that writers like

16 Cf. R. MacMullen, Enemies of the Roman Order (Cambridge University Press, Cambridge, 1966), pp. 1-94.

17 See K. Coleman, 'The Emperor Domitian and Literature', $A N R W$ II (1986), pp. 3087-3115, esp. pp. $3105-15$.

18 McGuire, Acts of Silence (as in n. 14), pp. 63-85.

19 See F. Ahl, 'The Art of Safe Criticism in Greece and Rome', AJP 105 (1984), pp. 174-208.

20 For the Platonic and other classical resonances in this account, see M. Luz, 'Eleazar's Second Speech on Masada and its Literary Precedents', Rheinisches Museum für Philologie 126 (1983), pp. 25-43. 
Silius did. In contrast to the Stoic ideal of suicide as a calm and rational act, the Flavian poets often stressed its irrationality, associating it with savage ferocity or frenzied madness. Josephus does the same thing in the Masada story. While Elezar's speech creates a first impression of reasoned and calm deliberation, that impression quickly breaks down as his followers, 'overpowered by some uncontrollable impulse,' cut him off and rush about 'like men possessed' (7.389). ${ }^{21}$ Statius' account of the Saguntine mass suicide insinuated an analogy with the fratricidal violence of civil war: 'Against their will men stain their hands with kindred blood.' The Masada narrative evokes a similar image of kindred strife: 'while they caressed and embraced their wives and took their children in their arms, clinging in tears to those parting kisses, at that same instant, as though served by hands other than their own, they accomplished their purpose' (391-92). The reader's confusion about what Josephus himself thinks about the Masada narrative - does he admire the suicide of the Sicarii or condemn it? - is not just the result of reading this story in relation to Josephus' rejection of suicide for himself earlier in the Jewish War. The narrative works to elicit this response by inscribing it into the narrative as the response of the suicides themselves as they vacillate between pity for their loved ones and brutal resolve - another technique Josephus shares with his Roman contemporaries as we have seen.

The Masada story may have a somewhat different compositional history than that of the rest of the Jewish War, there being reason to think that Josephus wrote book 7 of this narrative much latter than the rest of the work. ${ }^{22}$ In its ambivalence, however, this scene is of a piece with the rest of Josephus' literary corpus. His account of Pompey's conquest of the Temple features a description of how those within the Temple allowed themselves to be killed or took their own lives rather than surrender to the Romans. The scene fuses positive and negative elements in much the same way that the Masada story does. Again, the initial signals are quite favourable. Noting that the Jews were ready to risk their lives to contnue with the sacrificial service, Pompey 'was filled with admiration for (their) invariable fortitude' ( $J . W$. 1.148). When the Romans break into the Temple, the priests embody steady calmness and piety, remaining 'unperturbed' as they are butchered in the act of sacrifice, 'putting the worship of the Deity above their own preservation' (1.150). But then the narrative swerves into madness and fratricidal violence: 'Most of the slain perished by the hands of their countrymen of the opposite faction (the latter phrase reflects a word related to the Greek word for factionalism) ... some, driven mad by their hopeless plight, set fire to the buildings around the wall and were consumed in the flames' (151). In another scene, Josephus presents two judgements of voluntary death side by side, wondering what it was that impelled Sicarii rebels captured in Egypt to accept death at the hands of the Romans rather than acknowledge Caesar as Lord. Was it courage, he asks, or

${ }^{21}$ For these and other negative elements in the Masada story, frequently obscured in translation, see D. Ladouceur, 'Josephus and Masada', Josephus, Judaism and Christianity, ed. L. Feldman and G. Hata (Wayne State University Press, Detroit, 1987), pp. 95-113.

22 See S. Schwartz, 'The Composition and Publication of Josephus's "Bellum Iudaicum” book 7', HTR 79 (1986), pp. 373-86. 
'the loss of (their) mind?' (7.417). He leaves the reader suspended between the two possibilities.

To understand what Josephus is up to, we must resist the impulse to favour one interpretation over the other. It is tempting to focus on the narrative's negative signals, as Ladouceur does, and conclude that Josephus was seeking to insinuate his opposition to suicide. He certainly had reason to distance himself from any topic that might smack of subversion. Despite his service to the Flavian emperors, his previous career as a Jewish rebel probably left his loyalty suspect in imperial eyes, and indeed, as late as Domitian's reign, he was dogged by accusations of treason (Life 428.29). As he himself acknowledges, moreover, he would not have succeeded as an historian if his account of the Jewish Revolt had not secured Flavian favour. ${ }^{23}$ For a writer in Josephus' position, endorsing self-killing, especially that undertaken in direct opposition to the Flavians as was the case during the Jewish Revolt, could easily prove, well, suicidal. While I do not reject this way of reading Josephus, however, his rhetoric's positive signals must also be factored into the equation. Why, if Josephus sought to discredit suicide, did he give Eleazar such noble motives? Why report the Romans' admiration for the act? Why risk saying anything positive about the act at all?

One can imagine a number of possible motives. Whatever reservations Romans in the Flavian period had about suicide, 'noble death' clearly continued to have heroic resonance, and a Jewish author might benefit from identifying his writing with that tradition. Seeking to flatter his imperial patrons, Josephus seems to have tried to establish the Jews as an 'equal opponent,' an enemy the Flavians could take pride in defeating because of their fearlessness and contempt of death, and his suicide accounts, mirroring the noble deaths of Roman warriors, would serve that strategem well. ${ }^{24}$ It is also conceivable that Josephus' own authority as an historian was at stake in these stories. Why should a wary reader believe what Jews like Josephus said about their history and not the counter-histories of Greek critics? Josephus' answer to this question in Against Apion appeals to the history of Jewish voluntary death: Jews have proven time and again that they would sooner give up their lives before altering a single syllable of their sacred records, unlike the Greeks who would not bare the smallest injury to save their whole library (Against Apion 1. 42-44). An intended effect of his suicide accounts, this claim suggests, was to corroborate how Jews represent the past, proving their (and by extension Josephus' own) resolve to transmit historical memory exactly as inherited from their ancestors. ${ }^{25}$

\footnotetext{
${ }^{23}$ See Life 363, where Josephus boasts that Titus personally endorsed the Jewish War as the official account of the war, affixing his own signature to it.

24 Cf. Newell, 'Forms and Historical Value' (as in n. 6), pp. 289-90. For the concept of the 'equal opponent', see Carlin Barton, The Sorrows of the Ancient Romans: The Gladiator and the Monster (Princeton University Press, Princeton, 1993), pp. 182-83.

25 Josephus develops this theme in his account of the Maccabean Revolt in the Antiquities, where the Jews' willingness to die for their law proves that it was they, and not the Samaritans, who were the true heirs to that law. During Antiochus' persecution, when practising the law was liable to get one killed, the Samaritans renounced their allegiance to it and claimed to be 'colonists from the Medes and the Persians' (Ant. 12.257). In contrast, the Jews, especially the
} 
Such inferences focus only on the positive signals sent by Josephus' suicide accounts, those elements that draw empathy or admiration from the reader. They discount the ways in which these scenes obstruct or undercut a favourable evaluation. Within a culture such as developed in late first century Rome, however - where the art of saying two things at once was promoted as a useful survival skill — each way of reading Josephus does not necessarily preclude the other. Indeed, the parallel with Flavian epic helps to clarify how an author in this period might actively encourage contradictory readings of his suicide accounts, including using those killing themselves to model an equivocal reader response. We cannot say for certain whether Flavian Epic had any direct influence on Josephus's narrative technique (a more comprehensive comparison is a desideratum), but Josephus did hone his narrative technique in the same cultural matrix, and had to be mindful of the same imperial audience and its suspicions. Seeking to ingratiate himself with this audience, there was much for Josephus to gain by aligning Jewish history with the Romans' tradition of noble death, but there was also much to lose with that audience if it read his suicide accounts as a challenge to its own dominance. What we have seen here suggests that Josephus found a solution to this predicament in the Romans' own literary practice, a cultivated ambivalence that conveyed the heroism of suicide while blunting its subversive potential at the same time.

This reading raises the vexed question of intention. Supposing that Josephus was influenced by contemporary Roman practice, can we be certain this influence was conscious, that he meant to seem ambiguous? Of course, there can be no definitive answer to this question; the evidence simply does not allow us to penetrate beyond the text into the mind that shaped it. Still, it is worth noting the role that suicidial equivocation plays in the historian's account of his own survival. To remain alive at Yodefat, Josephus had to adapt various attitudes in relation to suicide, first arguing against it (J.W. 3.361-82), then pretending to accept the necessity of committing it, or even sincerely going along with the plan - the text is ambiguous on this point (387-90) - then repenting of that decision at the last moment (391). Later, in a final twist, Josephus undercuts his own rejection of suicide somewhat when he admits to Vespasian that he knew it became a general to die and would have preferred to have done so had not God ordered him to live (J.W. 3.400). Josephus' vacillation is what saves his life, and its role as a survival tactic within Josephus' narrative makes it that much more credible to suppose that the vacillation of Josephus' suicide accounts was prompted by an analogously cunning survival instinct.

In fact, I am inclined to read Josephus' almost-suicide as a dramatisation of

Maccabees, were ready to die for the law (12.267). The difference in their responses underscores the authenticity of the Jews and the fickle allegiance of the Samaritans, just as the Jews' willingness to die for the law vouchsafed its representation of that past vis-à-vis the self-serving fictions of the Greeks. For more on how Josephus recasts the Maccabean revolt for his purposes, see I. Gafni, 'Josephus and 1 Maccabees', Josephus, the Bible and History (as in n. 6), pp. 116-31. For more on the martyrdom traditions of the Maccabean Revolt as depicted in other early Jewish sources, see T. Rajak, 'Dying for the Law: The Martyrs' Portrait in Jewish-Greek Literature', Portraits: Biographical Representation in the Greek and Latin Literature of the Roman Empire, ed. M. J. Edwards and Simon Swain (Clarendon Press, Oxford, 1997), pp. 39-67. 
this very rhetorical strategy, personified in the guise of the historian himself. Notice how this equivocation allows Josephus to manoeuvre at Yodefat-to reassure fellow Jews who expect voluntary death in such a circumstance even as he discredits suicide as an irrational and impious act, to reassure his Roman captors that he knows that a general should have died in such a circumstance even as he legitimises his survival. If what I have argued here is correct, Josephus was in a not dissimilar predicament at the time that he wrote this account, under pressure from Jewish tradition to endorse dying for the law, under pressure from Roman tradition to glorify noble death, but also vulnerable to the dangers of extolling suicide at a time when doing so could get an author executed. It is conceivable that his attempt to accommodate these conflicting pressures left a mark on his self-portrait. After all, we do not really know what happened at Yodefat. Besides Josephus, there was only one other person who saw what happened, the other surviving soldier, and we have to take Josephus' word for it that he saw things the same way (the existence of a second witness is suspiciously convenient for Josephus precisely because it seems to corroborate his account). By no means is this to discount the episode's testimony completely - at least the topography of the story, the cave where the suicide pact occurred, seems confirmed by the archaeology of Yodefat. ${ }^{26}$ Mathematicians have even deduced a way for Josephus to have manipulated the lottery to his advantage, surmising what number would be the last one standing through a calculation now known as the 'Josephus Permutation'. ${ }^{27}$ The facts leave plenty of room for an enterprising author to manoeuvre, however, and it seems clear that Josephus has skewed them to help excuse himself. What we have learned here can illumine why he told this story as he did, and its role in his larger rhetorical project: Josephus' almost-suicide not only mirrors the ambivalence of his Roman audience; it develops that ambivalence into a survival tactic, a way to enlist the Roman ethos of noble death to its own advantage without alienating an imperial rule deeply suspicious of suicide as a challenge to its authority.

\section{Virtual Death}

Being equivocal has its advantages as a survival tactic, but for Josephus it seems to have come at the cost of his reputation among fellow Jews. In the Jewish War, he acknowledges the sorts of criticisms raised against him in his own day, putting them into the mouths of his fellow soldiers who accused him - falsely he assures us - of forgetting himself by refusing to die when he had urged so many others to do so (J.W. 3.355-60). That Josephus felt it necessary to rebut these criticisms so explicitly reveals the downside to evading

${ }^{26}$ For the archaeological evidence bearing on the battle at Yodefat, see M. Aviam, 'Yodefat/Yodefat: The Archaeology of the First Battle', The First Jewish Revolt: Archaeology, History and Ideology, ed. A. Berlin and J. Overman (Routledge, New York, 2002), pp. 121-33. For a general analysis of the historical value of Josephus' suicide accounts endorsing their basic reliability in this regard, see Newel, 'Forms and Historical Value' (as in n. 6).

27 See I. Herstein and I. Kaplansky, Matters Mathematical (Harper \& Row, New York, 1974), pp. $121-28$. 
the act of suicide in a culture that expected it of defeated heroes.

To this day, in fact, Josephus' survival still disappoints readers, even though we would not have the Jewish War without it. Why would Josephus tell us a story about himself that was so unflattering? Reading this episode against the backdrop of contemporary Roman narrative suggests an answer: Josephus' portrait of himself works well as an attempt to navigate the conflicting impulses of a culture deeply ambivalent about suicide. In fact, Flavian Epic produced at least one hero able to manoeuvre between suicide and survival in much the same way Josephus did. In book 11 of the Punica, an account of a mass suicide at Capua, Silius introduces Decius, a character whose very name encapsulates the promise of noble self-sacrifice by recalling the Decii of early Roman history who sacrificed their lives in battle to save their people. Decius evokes this tradition in a speech to his fellow Capuans in which he resolves to take his own life rather than do the wrong thing: 'The greatest boon with which grudging nature has equipped man is this - that the door of death stands open and suffers us to depart from a life that is too hard' (11.186-88). Later in the narrative, he seems poised to act on this impulse, refusing to run away at the enemy's approach and declaring himself ready to die when taken captive (249-56). It is at this point, however, that the narrative takes an unexpected swerve from the tradition of noble death. With Jupiter's help, Decius is able to avoid death, escaping his captors and taking refuge in Egypt where he later dies peacefully (377-84). Silius never spells out what he thinks about Decius' escape, but he suggests nothing cowardly about it and indeed gives him a much happier ending than he does other Capuans who take their own lives, their suicides depicted as noble but morally questionable. ${ }^{28}$ The Josephus of the Jewish War follows the same basic trajectory as Decius, coming to the brink of voluntary death without going through with it. The parallel suggests that Josephus' self-portrait as a figure who comes to the point of committing suicide but is spared from having to do so, has been conditioned in some way by the ambivalence that characterises the suicide accounts of contemporary Roman authors.

In fact, Josephus is not the only figure in the Jewish War who follows this trajectory. The Jewish people as a whole do so on two occasions, both involving a threat to the survival of their traditions. The first occurs when the procurator Pilate attempts to install imperial images in Jerusalem, an outrageous act that would violate the Jewish taboo against images. To stop him, the Jews are ready to sacrifice their own lives, but find that they do not have to do so in the end:

The Jews, as by concerted action, flung themselves in a body on the ground, extended their necks, and exclaimed that they were ready rather to die than to transgress the law. Overcome with astonishment at such intense religious zeal, Pilate gave orders for the immediate removal of the standards from Jerusalem. (J.W. 2.174)

The Jews respond similarly a few decades later when the Roman governor

28 McGuire, Acts of Silence (as in n. 14), pp. 219-25. 
Petronius attempts to install a statue in the Temple:

At this the multitude cried out that they were ready to endure everything for the law. Petronius, having checked their clamour, said, 'Will you then go to war with Caesar?' The Jews replied that they offered sacrifice twice daily for Caesar and the Roman people, but that if he wished to set up these statues, he must first sacrifice the entire Jewish nation; and that they presented themselves, their wives, and their children, ready for the slaughter. These words filled Petronius with astonishment and pity at the spectacle of the incomparable devotion of this people to their religion and their unflinching resignation to death. So for the time he dismissed them. (J.W. 2.196-98)

In both of these narratives, the Jews declare themselves ready to die, but they do not have to in the end, for amazed at their resolve, the Romans withdraw of their own accord. The Jews in these episodes behave as nobly as the Masada rebels, coming to the very point of voluntary death, and indeed, like the Masada account, Josephus reinforces the impression of heroic resolve by noting the admiring reaction of the Romans who witness it. In contrast to the rash or frenzied Jews typically featured in the historian's other suicide accounts, however, these stop short of taking their own lives. In a sense, they offer their target audiences, Pilate and Petronius, a choice as to what kind of conclusion they want - suicide or survival with integrity - and the Romans, impressed by the Jews' willingness to die, consistently opt for the latter. In the end, the Jews in these scenes are more akin to Decius and Josephus' selfportrait than they are to the Masada rebels, ready to die but opting to live when the opportunity presents itself - only in this case, it is their willingness to die, and the impression this makes on the Romans who witness it, that makes survival possible.

Josephus was a historian, not a fiction writer, and he did not make up these scenes from scratch. We have an earlier account of the Petronius incident, in fact, narrated by Philo in his Embassy to Gaius, and it too features the suicide threat, rendered much more dramatically that Josephus' terse report. While he did not invent these episodes, however, there is reason to suspect that Josephus tampered with his sources to stock his narratives with multiple would-be suicides such as himself. In Embassy 299-305, Philo narrates another incident that resembles the Pilate affair as recounted by Josephus in which the procurator offends Jewish religious sensibilities by installing some golden shields in Herod's palace. The two scenes diverge in a number of respects. The most significant difference for our purposes concerns how the Jews are able to stop Pilate in each scene: whereas in Josephus' account, Pilate is stopped in his tracks by the awesome sight of the Jews ready to die for their tradition, Philo claims that he only desisted from his sacrilegious plans when the Jews went over his head to the emperor Tiberius. This and other differences have led scholars to conclude that Philo and Josephus were in fact referring to two separate crises, but it is hard to believe that Pilate would make the same mistake twice. ${ }^{29}$ More recently, therefore, Daniel Schwartz has argued for reading

\footnotetext{
29 See, for example, M. Smallwood, 'Philo and Josephus as Historians of the Same Events', Josephus, Judaism and Christianity (as in n. 21), pp. 114-29.
} 
the two stories as variant accounts of the same event, Josephus's version adjusted to furnish yet another example of his thesis that the Jews had always been ready to die for the law. ${ }^{30}$ To nuance this conclusion, I would argue that Josephus' revision actually reshapes this episode to fit the same literary mould that he himself reflects in the Yodefat incident, the heroic Jew poised to die but ultimately spared from having to do so.

In his second major narrative, The Antiquities, Josephus draws on existing interpretive motifs to develop this intermediate pose into something of a Jewish heroic tradition. Like the Jewish War, the Antiquities is chock full of morally ambiguous suicide reports. For instance, in his retelling of Judges 11, where the judge Jepthah offers up his daughter as a sacrifice to God, Josephus makes the daughter into a (somewhat) willing martyr, accepting death at her father's hand 'without displeasure'. Whatever admiration her selflessness elicits is immediately undercut, however, when Josephus notes that her sacrifice was a rash and irrational act, "neither sanctioned by the law nor wellpleasing to God' (Ant. 5.263-66). ${ }^{31}$ But it would be wrong to conclude from this and other implicit criticisms in The Antiquities that it seeks to discredit the act of voluntary death altogether. Note, for instance, how it seizes on the Samaritans' refusal to die during Antiochus' persecution to discredit them as imposters (Ant. 12.257). The ideal in the Antiquities, as in the Jewish War, lies between noble death and pragmatic survival, what I would refer to as the act of would-be martyrdom.

The first hero Josephus places in this tradition is Abraham's son Isaac. Josephus makes Isaac a joyful participant in his sacrifice, rushing to the altar himself, but of course, at the last moment, he is spared by God and granted a long life (Ant. 1.232-34). Josephus was not the only early Jewish exegete to portray Isaac in this way. He also appears as a willing victim in Pseudo-Philo's Biblical Antiquities 32:2-3, 4 Maccabees 13:12, and 1 Clement 31:2-4, all from the first or second century C.E., suggesting that Josephus was drawing on a widely spread exegetical tradition. ${ }^{32}$ Within the context of the Antiquities, however, Isaac's near-martyrdom is part of a larger pattern also reflected in his retelling of 1 Maccabees. As he dies, the father of the Maccabees, Mattathias, urges his sons:

to remain constant as such and to be superior to all force and compulsion, being so prepared in spirit as to die for the laws, if need be, and bearing this in mind, that when the Deity sees you so disposed, He will not forget you, but in admiration of your heroism will give them back to you again, and will restore to you your liberty. (Ant. 12.281)

Josephus is paraphrasing here a pre-existing source, 1 Maccabees 2:4964 - Now, my children, show zeal for the law, and give your lives for the

\footnotetext{
30 D. Schwartz, 'Josephus and Philo on Pontius Pilate', Josephus Flavius: Historian of Eretz Israel in the Hellenistic-Roman Period, ed. U. Rappaport (Yad Izhak Ben Zvi, Jerusalem, 1982), pp. 217-36 (in Hebrew).

31 Cf. L. Feldman, Studies in Josephus' Rewritten Bible (Brill, Leiden, 1998), pp. 189-91.

32 See J. Kugel, The Bible as it Was (Harvard University Press, Cambridge, MA, 1997), pp. $174-75$.
} 
covenant ...'-but he has altered his source to allow for the possibility that the Maccabees do not actually have to die to achieve salvation: merely being 'prepared in spirit as to die' can insure God's protection. The ensuing history of the Maccabean revolt as Josephus tell us bears this out, for when the enemy commander sees that the Maccabees are 'prepared to die if they could not live as free men,' he retreats in fear at their resolve, a victory that made it possible for the Maccabees to reclaim the Temple. ${ }^{33}$ In a paradox familiar from Josephus' account of the Pilate and Petronius incidents, showing the willingness to be a martyr saves Jewish tradition along with those who would die to defend it.

In these earlier scriptural or near-legendary events, what allows Jews to escape death in the end is divine intervention, God sparing would-be martyrs like the Maccabees because $\mathrm{He}$ is impressed by their willingness to die. Once Josephus' narrative gets to the Roman period, interestingly, the Roman authorities take God's place in this drama, showing mercy because they are impressed by the Jews' willingness to die. This, I think, is an important clue for understanding why Josephus tells this sort of story. His intended audience, Roman readers and most especially the Flavian dynasty, was of two minds about suicide, predisposed by their own tradition to admire it, but with reservations about its viability as a form of resistance. Jewish history as Josephus reconstructs it, a narrative that makes Jewish survival dependent on showing one's intention to die without completing the act, represents an effort to accommodate these conflicting impulses by creating a new kind of hero, the virtual martyr who accomplishes what actual martyrs like those of the Maccabean period did—safeguarding their religious tradition, preserving their dignity and autonomy, winning renown — but without the irrevocable defiance that fully fledged suicide signified.

By telling the reader of his own almost-suicide at Yodefat, Josephus places himself within this heroic tradition. Commentators almost invariably interpret Josephus' behavior at Yodefat as deceitfully manipulative. ${ }^{34}$ So did some ancient readers (the Slavonic translation of Josephus asserts, for instance, that he willfully deceived his fellow soldiers ${ }^{35}$ ). While professing to 'resourcefulness' ( $J . W .3 .387)$, Josephus himself never actually admits to deceit; to the contrary, even though he believed it was better to surrender than to die, he still wishes for death, praying that the Romans betray him: 'if, after pledging their word, they put me to death, I shall die content' (382). Unlike his fellow soldiers, however, he was also able to recognise the shortcomings of suicide. One aspect of suicide that particularly troubled Flavian poets was its self-

\footnotetext{
33 Josephus produced this story through a revision of 1 Macc. 4:35: 'When Lysias saw the rout of his troops and observe the boldness that inspired those Judas, and how ready they were to live or die nobly, he withdrew to Antioch.'

${ }^{34}$ See, for instance, S. Cohen, Josephus in Galilee and Rome: His Vita and Development as a Historian (Brill, Leiden, 1979), pp. 228-30.

35 'He counted the numbers with cunning, and thereby misled them all.' For an English translation of this passage, see the appendix to the Loeb edition, H. St. J. Thackeray, Josephus, The Jewish War Books V-VII (Harvard University Press, Cambridge, MA, 1928), p. 456.
} 
censoring effect; suicide silenced the protest that motivated it. ${ }^{36}$ Josephus was mindful of this effect as well, realising that if he killed himself he would not be able to deliver his divine message to Vespasian (361). Take his testimony at face value, then, and Josephus emerges as the perfect hero for the Flavian age, ready to die a noble death but led by reason and a fear of self-censorship to remain alive instead and attach his fortunes to the Flavians.

Josephus' account of this episode reflects a real struggle for survival, although not necessarily the one that saved the historian during the Jewish Revolt. The risks of writing about suicide in the Flavian period were sufficiently great that when Josephus' contemporaries, the Flavian poets, take up the subject, they employ what has come to be known as the 'arts of safe criticism' - ambiguity, equivocation, and other rhetorical techniques used by orators in this period to avoid being read as treasonous. For an author like Josephus, on the other hand, writing about suicide could also be conducive to survival, strengthening his appeal to Roman readers, augmenting the Flavians' glory in defeating the Jews, and buttressing his authority as narrator. Josephus seems to have found two ways to exploit such stories to his own advantage while minimising the attendant risks. The first was to narrate suicide with reservations, describing it in heroic terms but in a way that saps its subversive potential. The second was to construct the image of virtual martyrdom, being willing to die, coming to the point of death, but stopping short for some reason. In the Yodefat episode, Josephus manages to tell both stories at once, casting his fellow soldiers in the role of heroic suicides led tragically astray by mad desperation, and casting himself as the would-be martyr. Here as in other episodes, the pose of virtual martyrdom works in Josephus' narrative as a survival tactic, and that, I am suggesting, is how the telling of these stories was meant to work as well, enhancing his prospects for literary success in Flavian Rome and deflecting interpretations that could conceivably prove fatal.

\section{Suicide as Compact}

Josephus does little in the end to settle whether martyrdom was an indigenously Jewish concept or the result of interaction with Roman culture. To be sure, he understood dying for the law as an innately Jewish trait, born of an instinctive commitment to God and His laws that manifests itself repeatedly in Jewish history, from the days of Isaac's willing sacrifice to the mass suicide of Masada - a support for Frend's view of things. And yet, Josephus' very assertion of this tradition - its role in his narrative as an impressive spectacle, its association with authenticity, the negative insinuations that undercut its heroic lustre - all suggest the influence of Roman cultural tradition - and in fairly precise ways if my analysis is correct. This accords with Bowersock's perspective. Josephus, who on the subject of voluntary death does not lend himself to 'either-or' readings as we have seen, only makes it that much harder to disentangle the relative contributions of Jewish and Roman cultures.

36 McGuire, Acts of Silence (as in n. 14), p. 203. 
While complicating the question of what is Jewish and what is Roman in early Jewish martyrdom, Josephus does enrich our understanding of how ancient Jews themselves related these cultural traditions to one another. Within the world that Josephus describes in his narratives, many Jews, like the Romans themselves, opt for death as a way to resist imperial rule, turning to it as a last resort when there was no other way to preserve their freedom or their traditions. If what I have argued here is correct, for Josephus himself, voluntary death was not a site of contestation or struggle between Jews and Romans; to the contrary, it reflected a shared ethos - an uncompromising love of freedom and tradition, and a noble contempt for death - that transcended the differences between Jews and Romans and could even reconcile one to the other as it did in the days of Pilate and Petronius. For this reason, I would hazard to guess that Josephus would not have been displeased at our inability to distinguish what is Jewish from what is Roman in his suicide narratives. For as he constructs these accounts, voluntary death is as a key point of convergence between the Jews and the Romans, where each found something to relate to in the other. 